\title{
Effect of phosphorus applied as monoammonium phosphate-coated polymers in corn culture under no-tillage system
}

\section{Doses de fósforo na forma de polímeros revestidos de monoamônio fosfato na cultura do milho em sistema plantio direto}

\author{
Ana Carolina Marostica Lino ${ }^{1}$; Salatiér Buzetti²; \\ Marcelo Carvalho Minhoto Teixeira Filho²; Fernando Shintate Galindo ${ }^{3 *}$; \\ Paulo Ricardo Maestrelo ${ }^{1}$; Mateus Augusto de Carvalho Rodrigues ${ }^{1}$
}

\begin{abstract}
The use of phosphate fertilizers as coated polymers reduces phosphorus losses that occur by adsorption of $\mathrm{P}$ to soil particles, thereby providing this essential nutrient for a longer period. The objective of this study was to evaluate the effect of phosphorus doses applied as conventional monoammonium phosphate or as coated polymers on corn grown in a clayey Oxisol, in the Cerrado region. The experiment was conducted in Selvíria - MS, located at $22^{\circ} 22^{\prime} \mathrm{S}$ and $51^{\circ} 22^{\prime} \mathrm{W}$. The experiment was laid out in a randomized block design arranged as a $4 \times 2$ factorial, with four doses of $\mathrm{P}_{2} \mathrm{O}_{5}(0,50,100$, and $150 \mathrm{~kg} \mathrm{ha}^{-1}$ ) and two sources of phosphorus (monoammonium phosphate (MAP) and monoammonium phosphate coated polymers). The experiment was conducted under no-tillage system during the cropping seasons in 2008/09 and 2009/10. The MAP and MAP-coated sources did not differ in most of the yield components in either of the two seasons. We found a quadratic function adjustment for $\mathrm{P}$ doses up to 117 and $98 \mathrm{~kg} \mathrm{ha}^{-1}$ of $\mathrm{P}_{2} \mathrm{O}_{5}$ for $\mathrm{P}$ concentration in leaf tissue and grain yield in the 2008/2009 crop, respectively. We also obtained a quadratic function adjustment for $\mathrm{P}$ rates for grain yield and number of plants, up to 118 and $113 \mathrm{~kg} \mathrm{ha}^{-1}$ of $\mathrm{P}_{2} \mathrm{O}_{5}$, respectively, in the 2009/2010 harvest.
\end{abstract}

Key words: Zea mays L. Enhanced efficiency fertilizer. Phosphate fertilizer.

\section{Resumo}

O uso de fertilizantes fosfatados revestidos por polímeros pode causar redução de perdas de fósforo, que ocorrem principalmente pela fixação do $\mathrm{P}$ aos colóides do solo, disponibilizando assim, esse importante nutriente por mais tempo. Neste contexto, objetivou-se avaliar o efeito de doses de fósforo usando o monoamônio fosfato convencional e o revestido por polímeros na cultura do milho em solo da região de Cerrado. O experimento foi conduzido em Selvíria - MS, com coordenadas geográficas de $20^{\circ} 22^{\prime}$ de latitude $\mathrm{S}$ e $51^{\circ} 22^{\prime}$ de longitude $\mathrm{O}$, num Latossolo Vermelho distrófico de textura argilosa. O delineamento experimental foi o de blocos ao acaso, dispostos em esquema fatorial $4 \times 2$, sendo 4 doses de $\mathrm{P}_{2} \mathrm{O}_{5}\left(0,50,100\right.$, e $\left.150 \mathrm{~kg} \mathrm{ha}^{-1}\right)$ e 2 fontes de fósforo (monoamônio fosfato e monoamônio fosfato revestido por polímeros). O experimento foi conduzido sob sistema plantio direto nas safras de 2008/09 e 2009/10. As fontes MAP e o MAP revestido não diferiram na maioria dos componentes produtivos nas duas safras. Houve ajuste em função quadrática para doses de $\mathrm{P}$ na concentração de $\mathrm{P}$ foliar e produtividade de grãos na safra de 2008/2009, até a dose de 117 e $98 \mathrm{~kg} \mathrm{ha}^{-1}$ de $\mathrm{P}_{2} \mathrm{O}_{5}$ para a concentração

\footnotetext{
${ }^{1}$ Eng $^{\text {os }}$ Agr $^{\text {os }}$, Universidade Estadual Paulista, UNESP, Campus de Ilha Solteira, Ilha Solteira, SP, Brasil. E-mail: carol_marostica@ hotmail.com; paulomaestrelo@hotmail.com; mateusdinho@hotmail.com

2 Profs. Drs., UNESP, Ilha Solteira, SP, Brasil. E-mail: sbuzetti@agr.feis.unesp.br; mcmtf@yahoo.com.br

${ }^{3}$ Discente, Curso de Pós-Graduação em Agronomia, UNESP, Campus de Ilha Solteira, Ilha Solteira, SP, Brasil. E-mail: fs.galindo@ yahoo.com.br

* Author for correspondence
} 
de $\mathrm{P}$ no tecido foliar e produtividade de grãos, respectivamente, e ajuste em função quadrática para doses de $\mathrm{P}$ na produtividade e número de plantas, até 118 e $113 \mathrm{~kg} \mathrm{ha}^{-1}$ de $\mathrm{P}_{2} \mathrm{O}_{5}$, respectivamente, na safra de 2009/2010.

Palavras-chave: Zea mays L. Fertilizante de eficiência aprimorada. Adubação fosfatada.

\section{Introduction}

Corn (Zea mays L.) is one of the most nutritious and cultivated foods in the world. Although Brazil is the third largest corn producer worldwide, behind the United States and China, its productive potential is still far below the productive capacity of the crop (GALINDO et al., 2016).

Fertilization is one of the factors that most affects the productivity and sustainability of agriculture, therefore, fertilizer consumption by the corn crop in Brazil has grown remarkably in recent years, mainly because it has been demonstrated to increase crop productivity (ARAÚJO, 2011; SOUZA et al., 2016; MELLO et al., 2017). Phosphorus (P) is one of the most limiting nutrients for agricultural crops (CHIEN et al., 2011; MCLAUGHLIN et al., 2011), especially in soils of tropical regions, which are generally low in $\mathrm{P}$ and moderately to highly acidic (ARAÚJO, 2011). They also show low utilization of phosphate fertilizers, due to $\mathrm{P}$ adsorption by soil $\mathrm{Fe}$ and $\mathrm{Al}$ oxides, prompting deficiency problems and plant malnutrition (BANSIWAL et al., 2006; SILVA et al., 2012; GAZOLA et al., 2013). Another factor that must be considered is the demand for phosphorus by the crop. Plants of intense and shortcycle development, such as the corn plant, require higher amounts of phosphorus in solution and faster adsorbed-P replenishment than plants of perennial crops (CORRÊA et al., 2008).

Phosphorus is usually supplied as soluble phosphate fertilizers at the time of sowing, but due to its high adsorption capacity in clayey soils, high doses are necessary to obtain economically viable yields. To overcome the problem of soluble phosphates costs associated with conventional solubilization processes, the use of alternative sources of phosphorus has been proposed (HARGER et al., 2007).
One way to reduce phosphorus losses is through gradual or controlled release of the nutrient contained in fertilizers. These fertilizers are called slow-release fertilizers, such as the polymerized fertilizers (MACHADO; SOUZA, 2012; GAZOLA et al., 2013). According to Figueiredo et al. (2012), the use of polymerized phosphorus is a new option for the reduction of $\mathrm{P}$ adsorption by soil colloids. However, because it is a relatively new product in terms of research, little is known about its behavior in acid soils. Valderrama et al. (2009) reported that the use of slow-release P sources may lead to lower production costs and lower environmental impacts, while reducing $\mathrm{P}$ fixation losses.

According to Gazola et al. (2013), the gradual release promoted by the phosphate fertilizer coating, such as MAP (soluble source), theoretically causes a significant reduction of phosphorus contact with $\mathrm{Fe}$ and $\mathrm{Al}$ oxides and the clay in the soil. Therefore, the formation of compounds that decreases nutrient predisposition to be adsorbed on the soil particles drops drastically, whereby polymer-coated fertilizers can ensure lower losses and greater $\mathrm{P}$ availability for plant growth over time.

Nevertheless, most studies carried out in Brazil have shown that polymer-coated phosphate fertilizers and conventional fertilizers have the same effectiveness for corn nutrition and grain yield. Hence, the coating has not been significantly effective in tropical edaphoclimatic conditions, such as the Cerrado savanna region, where high temperatures prevail. Thus, there is still a need for further research into the development of polymers for coating or supplying phosphate fertilizers, which can provide phosphorus to crop plants more effectively and efficiently.

In view of the above, the objective of this study was to evaluate the effect of phosphorus doses in 
the form of conventional MAP and polymer-coated MAP, on the nutritional state, yield components, and grain yield of corn grown under no-tillage system.

\section{Material and Methods}

The experiment was conducted during the $2008 / 2009$ and $2009 / 2010$ cropping seasons in the municipality of Selvíria, MS, at $20^{\circ} 22^{\prime} \mathrm{S}$ and $51^{\circ} 22^{\prime}$ $\mathrm{W}$ and $335 \mathrm{~m}$ above sea level; . According to the Brazilian Soil Classification System (EMBRAPA, 2013), the soil at the experimental site is a clayey Dystrophic Red Latosol, originally occupied by Cerrado savanna native vegetation and later cultivated with annual crops for more than 25 years.

According to Köppen, the climate of the region is of the Aw type, defined as tropical humid, rainy in the summer and dry in winter. The annual mean temperature in the region is around $23.5^{\circ} \mathrm{C}$; annual mean rainfall is $1370 \mathrm{~mm}$ and annual mean relative humidity ranges from 70 to $80 \%$. The mean values of climatic variables during the duration of the experiments are shown in Figure 1A and 1B.

The soil chemical characteristics were determined according to the methodology proposed by Raij et al. (2001) before the establishment of the corn experiment in the first crop season (2008/2009). Soil analysis results were as follows: $22 \mathrm{mg} \mathrm{dm}^{-3} \mathrm{P}$ (resin); $29 \mathrm{~g} \mathrm{dm}^{-3}$ organic matter; $\mathrm{pH} 5.4\left(\mathrm{CaCl}_{2}\right)$; $\mathrm{K}^{+}, \mathrm{Ca}^{2+}, \mathrm{Mg}^{2+}, \mathrm{H}+\mathrm{Al}=2.2,31.0,16.0$, and 29.0 $\mathrm{mmol}_{\mathrm{c}} \mathrm{dm}^{-3}$, respectively, and $63 \%$ base saturation.

The experiment was laid in a randomized blocks design arranged in a $4 \times 2$ factorial scheme with four replicates. Four $\mathrm{P}_{2} \mathrm{O}_{5}$ doses $(0,50,100$, and $150 \mathrm{~kg} \mathrm{ha}^{-1}$ ) were applied at sowing in both cropping seasons using two sources of phosphorus, monoammonium phosphate and polymer-coated monoammonium phosphate.
The experiment was conducted under no-tillage system (the experimental area has a history of 8 years under this system) during the 2008/09 (after a wheat crop) and 2009/2010 (after a bean crop) cropping seasons. Herbicides glyphosate (1800 $\mathrm{g} \mathrm{ha}^{-1}$ ai) and 2,4-D (670 $\mathrm{g} \mathrm{ha}^{-1}$ ai) were used for desiccation. The AGROCERES AG 8088, an early simple hybrid, was sown, averaging 5.4 seeds per meter for a population density of 55000 plants ha ${ }^{-1}$. Experimental plots were $5 \mathrm{~m}$ in length with 4 rows spaced $0.90 \mathrm{~m}$ apart $\left(18 \mathrm{~m}^{2}\right)$ in both crops. Sowing was performed mechanically on November 6, 2008 and October 27, 2009, with an appropriate seeder for the no-tillage systems (NTS). After planting, the area was irrigated every $72 \mathrm{~h}$ approximately by sprinkle irrigation using a central pivot to deliver a water sheet of approximately $14 \mathrm{~mm}$ for seed germination. Seedlings emerged 5 days after sowing in both seasons.

The fertilization at sowing was performed with $30 \mathrm{~kg} \mathrm{ha}^{-1}$ of $\mathrm{N}$ (urea), and $80 \mathrm{~kg} \mathrm{ha}^{-1}$ of $\mathrm{K}_{2} \mathrm{O}$ (potassium chloride) equally for all treatments, based on the soil analysis and the fertilization recommendation table for an irrigated corn crop for the State of São Paulo, as described by Cantarella et al. (1997). Treatments were implemented using phosphate fertilization doses.

Herbicides tembotrione ( $84 \mathrm{~g} \mathrm{ha}^{-1}$ ai) and atrazine (1000 $\mathrm{g} \mathrm{ha}^{-1}$ ai) were used to control weeds, plus the addition of an adjuvant in the herbicide syrup, vegetable oil (720 $\mathrm{g} \mathrm{ha}^{-1}$ ai) in post-emergence. Application of methomyl (215 $\mathrm{g} \mathrm{ha}^{-1}$ ai) and triflumuron (24 $\mathrm{g} \mathrm{ha}^{-1} \mathrm{ai}$ ) was used for insect control.

Cover nitrogen fertilization ( $80 \mathrm{~kg} \mathrm{ha}^{-1}$ of $\mathrm{N}$ ) was applied $20 \mathrm{~cm}$ from the planting lines, at the stage of completely unfolded 6 leaves (V6). After nitrogen fertilization, the experimental area was irrigated by central pivot irrigation with a water sheet of approximately $14 \mathrm{~mm}$ to minimize nitrogen losses due to volatilization of ammonia, which occurs due to the hydrolysis of urea. 
Figure 1. Rainfall $(\mathrm{mm})$, mean temperature $\left(0^{\circ} \mathrm{C}\right)$ and relative humidity $(\%)$ during the experimental period. (A) 2008/09 crop and (B) 2009/10 crop (B). Selvíria - MS.

A.

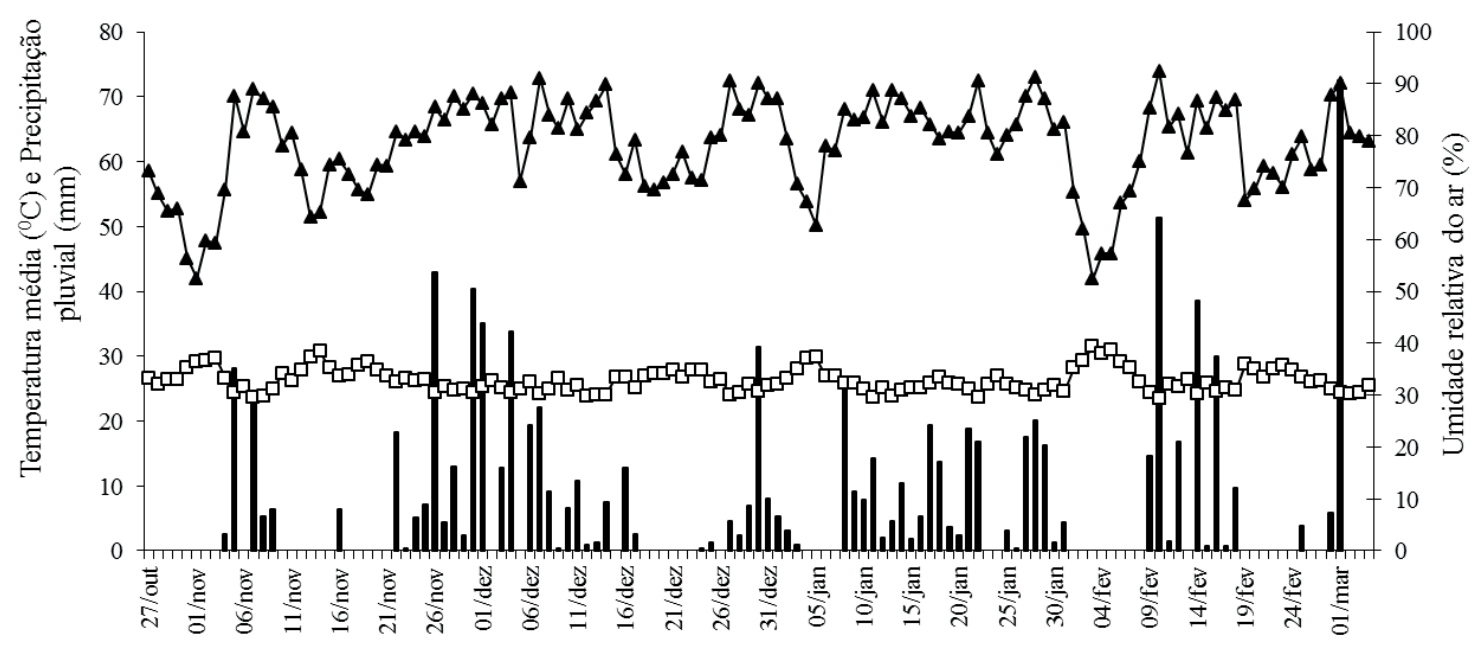

Período de condução do experimento (dia/mês)

-Precipitação $\quad \neg-$ Temp. média $\quad \rightarrow$-UR

B.

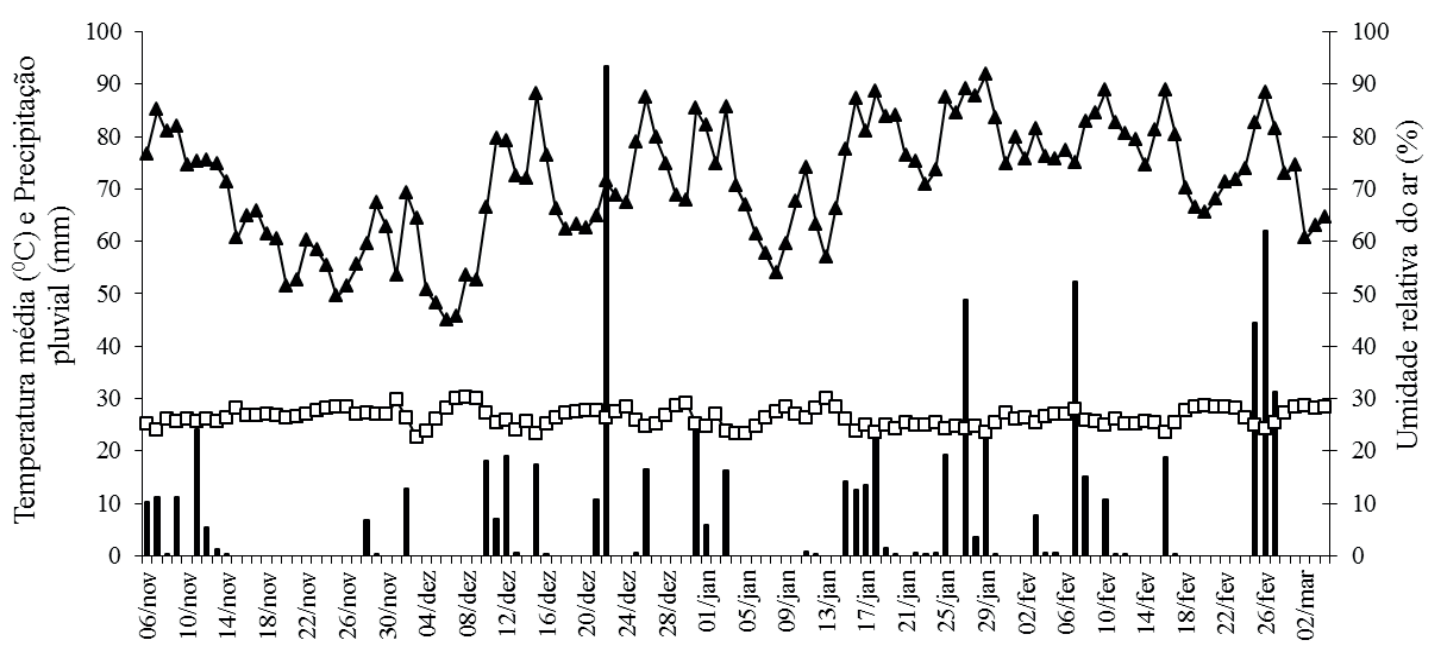

Período de condução do experimento (dias/mês)

When $95 \%$ of the corn cobs showed grains with $18 \%$ humidity they were harvested manually and individually in each experimental plot 118 and 128 days after emergence in 2009 and 2010, respectively. Only cobs from the central two rows from each plot were collected and then threshed.

Phosphorus concentration in leaf tissue was determined according to the methodology described by Cantarella et al. (1997). Samples were conditioned in paper bags, dried in a forced circulation oven at $65{ }^{\circ} \mathrm{C}$ for 72 hours and ground. Nutrient concentration was determined by molybdate blue spectrophotometry (MALAVOLTA et al., 1997). Leaf chlorophyll index (LCI) values were recorded at silking (R1), using a digital chlorophyllometer (CFL 1030 Falker) on the leaf 
of cob insertion in 10 plants per plot. Stalk basal diameter was determined at harvest on the second internode from the base of the plant in 10 plants per plot within the useful area of each plot, using a pachymeter $(\mathrm{mm})$. Height $(\mathrm{cm})$ of insertion of the first cob was obtained with a graduated ruler, measuring distance from the base of the stalk (above soil surface) to the main cob in 10 plants per plot, within working area. Plant height $(\mathrm{m})$ at maturity was recorded as the distance from soil level to tassel apex. These last three evaluations were carried out at harvest. Ten cobs randomly selected in the useful area of each plot were collected for manual counting of the number of grains per row, by counting grains in each row of cobs The number of grains per cob was determined by counting all grains on the cobs. The number of plants per hectare was determined by counting the plants in the two central lines of each plot. The data were quantified and transformed into plant number ha ${ }^{-1} ; 100$-grain weight was obtained after threshing of all cobs harvested in the useful area of the experimental plots. It was determined by manual counting of 100 grains, which were then weighed to $0.01 \mathrm{~g}$ accuracy. Grain moisture was determined by means of a portable multi-grain grain water content meter, which allowed for estimation of 100-grain weight corrected at 13\% moisture. Grain yield was determined by the collection of all cobs in the four central lines of each plot. After harvesting, mechanical threshing was performed; the grains were counted, and the data transformed in $\mathrm{kg} \mathrm{ha}^{-1}$ on a $13 \%$ (wet basis).

The data were submitted to analysis of variance and means were compared by Tukey's Test at the $5 \%$ probability level for $\mathrm{P}$ source effects. $\mathrm{P}$ dose effects were adjusted to regression equations. The SISVAR program was used for statistical analysis.

\section{Results and Discussion}

There were no significant phosphorus source effects on $\mathrm{P}$ concentration in leaf tissue, leaf chlorophyll index (LCI), stalk basal diameter, cob insertion height, plant height, number of grainrows, number of grains per cob, number of plants per hectare, 100-grain weight, or grain yield, for either crop season evaluated (Tables 1 and 2).

According to Mello et al. (2017), the responses of improved efficiency fertilizers depend on microbial action. Chemically altered fertilizers will convert some of the nutrients into insoluble forms that become available for plants gradually, whereas the covered or encapsulated formulations, such as those used in this research, consist in soluble compounds surrounded by a water-permeable resin that regulates the nutrient release process. Therefore, release will depend on soil temperature and humidity. It is worth pointing out that the rates of release and dissolution of water-soluble fertilizers also depend on coating materials. In addition, the thickness and chemical nature of the coating resin, the amount of microcracks on its surface and the size of the fertilizer granule determine the release rate of nutrients over time (GAZOLA et al., 2013). Thus, the type of polymer used as MAP coating were not efficient in the gradual release of phosphorus, probably because of the prevailing edaphoclimatic conditions in the region during the cropping seasons; i.e., high temperatures (Figures 1A and 1B), clayey soil and high microbial activity, which may have favored too rapid degradation of the polymer-coating. In addition, the fact that the crop was irrigated whenever necessary, may have attenuated the release and solubilization of phosphorus as a function of soil moisture.

According to Pavinato and Rosolem (2008), P behavior is differentiated according to the specific characteristics of each soil and organic matter decomposition activity with release of organic compounds, which have anionic behavior in the soil. The soluble organic compounds from decomposition of organic matter can act on the soil $\mathrm{P}$ availability, as proposed by Guppy et al. (2005). Another direct but negative effect of organic matter on the availability of $\mathrm{P}$ is the increase in the formation of bridges of metal bonds, increasing adsorption. On the other 
hand, the organic matter compound sorption may increase the negative charge on the soil surface, or decrease the zero-loading point (ZPL), hindering $\mathrm{P}$ adsorption (GUPPY et al., 2005). Yet, according to Pavinato and Rosolem (2008), it is also important to note that the increase in $\mathrm{P}$ availability may be due simply to the amount of P added via organic material, without interference of $\mathrm{P}$ originally present in the soil. That is, soil organic matter (SOM) performs an ambivalent role regarding $\mathrm{P}$ availability, as it may block adsorption sites on the surface of clays, iron oxides and aluminum (PEREIRA et al., 2010). The adoption of management systems that promote an increase in SOM content or its fractions may promote reduction of $\mathrm{P}$ adsorption by the formation of complexes that block adsorption sites on the surface of iron and aluminum oxides (TIRLONI et al., 2009). Hence, phosphate from both sources used in this study may have been made available by SOM; thus, explaining the similarity of treatment effects obtained by using these $\mathrm{P}$ sources in an agricultural area with a history of 8 years under notillage system.

Thus, the no tillage system can increase total organic carbon (TOC), and consequently decrease adsorption of phosphates and favor soil P levels, such as organic phosphorus (HERRERA et al., 2016; RODRIGUES et al., 2016). Organic phosphorus can be from 5 to $80 \%$ of total soil phosphorus and in tropical soils, it is a source of phosphorus to plants which must be considered in studies involving its dynamics and bioavailability (SANTOS et al., 2008). Organic phosphorus originates from senescent plant tissues recycled to the soil, microbial tissue, and the products of their decomposition (MARTINAZZO et al., 2007; SANTOS et al., 2008).

It should be noted that soil $\mathrm{P}$ content in the experimental area was in the range considered average by Raij et al. (1997), which is from 16 to 40 $\mathrm{mg} \mathrm{dm}^{-3}$ by the resin method. This is consistent with similar values for leaf $\mathrm{P}$ obtained for MAP forms in both 2008/09 and 2009/10 (Table 1). Phosphorus concentrations in leaves were in the appropriate range (2.0 to $4.0 \mathrm{~g} \mathrm{~kg}^{-1} \mathrm{P}$ on a dry weight basis) for the corn crop in 2009/10 and above the appropriate range in the 2008/09 campaign, in relation to that described by Cantarella et al. (1997), regardless of the $\mathrm{P}_{2} \mathrm{O}_{5}$ dose applied.

Another explanation, reported by Figueiredo et al. (2012), refers to the increase in base saturation to values as high as $60 \%$ (a similar value to that found in this research), which would likely have decreased the efficiency of the polymer-coated MAP, due to the exchange site saturation on these polymers with cations such as $\mathrm{Ca}^{2+}$ and $\mathrm{Mg}^{2+}$. This effect would in turn facilitate the precipitation of soluble phosphorus by the excess of these cations in the soil. This interpretation is supported by the findings of Valderrama et al. (2009), who did not find differences between simple conventional and polymerized superphosphate in a bean crop when the soil base saturation was $60 \%$. In contrast, Jagadeeswaran et al. (2005) found that, regardless of soil $\mathrm{pH}$, the polymer-coated fertilizer promoted greater phosphorus utilization efficiency, when compared to conventional MAP. Furthermore, working in the same study region, Valderrama et al. (2011) observed that yield and production of irrigated corn grain under no-tillage in a soil with average phosphorus content $\left(31 \mathrm{mg} \mathrm{dm}^{-3}\right)$ were the same after application of coated triple superphosphate or conventional triple superphosphate. Similarly, Gazola et al. (2013) could not verify a differential effect by coated MAP, compared to conventional MAP, on leaf $\mathrm{P}$ concentration, yield components or grain yield of corn in a soil with average phosphorus content ( $\left.22 \mathrm{mg} \mathrm{dm}^{-3}\right)$. Another report yet, by Collier et al. (2008), working with simple superphosphate and natural reactive phosphate (NAP), both at 180 $\mathrm{kg} \mathrm{P}_{2} \mathrm{O}_{5} \mathrm{ha}^{-1}$, could not find any difference in the yield components or grain yield of corn, that may be attributed to $\mathrm{P}$ source.

Nevertheless, contrary to the present report and those aforementioned, Figueiredo et al. (2012) found that polymer-coated MAP promoted improved corn yield, total dry matter mass production and plant height, compared to conventional MAP, at baseline 
saturation levels between $40 \%$ and $50 \%$. Zhang et al. (2006) also verified better responses by a wheat crop as to productivity and plant height, with the use of fertilizers coated with different polymers, in comparison with conventional fertilizers. On the other hand, Guareschi et al. (2011) found that application by free sowing of $\mathrm{KCl}$ and triple superphosphate, coated with polymers, 15 days before sowing, resulted in higher dry matter yield, higher number of pods per plant, and higher grain yield of soybean, in relation to the conventional formulations of these fertilizers. Yet, these authors verified that, when applied at sowing, these fertilizers produced the same soybean grain yield and dry matter yield.

According to Malhi et al. (2001), the use of slow-release phosphatic fertilizers may result in deficiency symptoms at the beginning of the season in some crops, and this deficiency may severely limit their productive potential. Nevertheless, this was not observed in the present study, as the use of MAP with or without coating was effective in promoting initial crop establishment. On average, $\mathrm{P}$ sources used were similar, differing only in function of $\mathrm{P}_{2} \mathrm{O}_{5}$ doses, which is supported by the findings of Silva et al. (2012).

Regarding the $\mathrm{P}_{2} \mathrm{O}_{5}$ dose, this had no differential effect on leaf chlorophyll index (ICF), stalk diameter, cob insertion height, number of grain rows per cob, number of grains per planting row, and 100-grain weight in the 2008/09 or 2009/10 harvests, nor for plant height or number of plants per hectare in the 2008/09 harvest (Table 1 and 2). Nevertheless, $\mathrm{P}_{2} \mathrm{O}_{5}$ dose influenced leaf $\mathrm{P}$ concentration and grain yield in the 2008/09 and 2009/10 harvests, and plant height and number of plants per hectare in the 2009/10 harvest. We observed a linear function for the variables leaf $\mathrm{P}$ concentration and plant height in the 2008/09 (Figure 2A) and 2009/2010 harvests (Figure 2B), respectively. Hence, the increase in $\mathrm{P}_{2} \mathrm{O}_{5}$ dose caused increased leaf $\mathrm{P}$ content and plant height. For leaf $\mathrm{P}$ concentration and number of plants per hectare in the 2009/10 crop, a quadratic function was adjusted with maxima at 117 (Figure 2B) and $113 \mathrm{~kg} \mathrm{ha}^{-1} \mathrm{P}_{2} \mathrm{O}_{5}$ (Figure 2D), respectively. Corn grain yield adjusted better to a quadratic function in the two harvests evaluated, with maxima at 98 (Figure 2E) and $118 \mathrm{~kg} \mathrm{ha}^{-1} \mathrm{P}_{2} \mathrm{O}_{5}$ (Figure 2F), respectively.

Table 1. $\mathrm{P}$ concentration in leaf tissue, leaf chlorophyll index (LCI), stalk diameter, cob insertion height and plant height as a function of $\mathrm{P}_{2} \mathrm{O}_{5}$ dose and source ${ }^{(1)}$. Selvíria - MS, 2008/09 and 2009/10.

\begin{tabular}{|c|c|c|c|c|c|c|c|c|c|c|}
\hline & \multicolumn{2}{|c|}{$\begin{array}{c}\text { P concentration in } \\
\text { leaf tissue } \\
\left(\mathrm{g} \mathrm{kg}^{-1} \text { of } \mathrm{MS}\right)\end{array}$} & \multicolumn{2}{|c|}{ LCI } & \multicolumn{2}{|c|}{$\begin{array}{l}\text { Stalk diameter } \\
(\mathrm{mm})\end{array}$} & \multicolumn{2}{|c|}{$\begin{array}{l}\text { Height of cob } \\
\text { insertion }(\mathrm{m})\end{array}$} & \multicolumn{2}{|c|}{$\begin{array}{l}\text { Plant height } \\
\text { (m) }\end{array}$} \\
\hline & $2008 / 09$ & $2009 / 10$ & $2008 / 09$ & $2009 / 10$ & $2008 / 09$ & $2009 / 10$ & $2008 / 09$ & $2009 / 10$ & $2008 / 09$ & $2009 / 10$ \\
\hline \multicolumn{11}{|l|}{ P source } \\
\hline MAP & $5.5 \mathrm{a}$ & $3.2 \mathrm{a}$ & $72.5 \mathrm{a}$ & $59.8 \mathrm{a}$ & $19.5 \mathrm{a}$ & $20.8 \mathrm{a}$ & $0.90 \mathrm{a}$ & $1.26 \mathrm{a}$ & $2.60 \mathrm{a}$ & $2.52 \mathrm{a}$ \\
\hline Coated MAP & $5.4 \mathrm{a}$ & $3.3 \mathrm{a}$ & $70.4 \mathrm{a}$ & $58.8 \mathrm{a}$ & $19.7 \mathrm{a}$ & $20.3 \mathrm{a}$ & $0.89 \mathrm{a}$ & $1.27 \mathrm{a}$ & $2.59 \mathrm{a}$ & $2.50 \mathrm{a}$ \\
\hline D.M.S. $(5 \%)$ & 0.2 & 0.1 & 3.7 & 2.1 & 1.0 & 1.9 & 0.04 & 0.03 & 0.05 & 0.04 \\
\hline \multicolumn{11}{|l|}{$\begin{array}{l}\mathrm{P}_{2} \mathrm{O}_{5} \text { dose } \\
\left(\mathrm{kg} \mathrm{ha}^{-1}\right)\end{array}$} \\
\hline 0 & $5.2^{* * k}$ & $2.9^{* * *}$ & 72.0 & 58.9 & 19.1 & 20.1 & 0.85 & 1.24 & 2.59 & $2.46^{*}$ \\
\hline 50 & 5.3 & 3.4 & 70.9 & 59.8 & 20.0 & 20.5 & 0.90 & 1.26 & 2.61 & 2.48 \\
\hline 100 & 5.5 & 3.3 & 70.7 & 59.0 & 19.3 & 20.2 & 0.92 & 1.27 & 2.58 & 2.56 \\
\hline 150 & 5.9 & 3.5 & 72.0 & 59.5 & 19.9 & 21.5 & 0.89 & 1.29 & 2.59 & 2.54 \\
\hline General Mean & 5.5 & 3.3 & 71.4 & 59.3 & 19.6 & 20.6 & 0.89 & 1.26 & 2.59 & 2.51 \\
\hline C.V. $(\%)$ & 5.8 & 3.8 & 7.0 & 4.8 & 6.7 & 12.6 & 6.35 & 3.19 & 2.46 & 2.17 \\
\hline
\end{tabular}

(1) Means followed by the same letters, in the column, do not differ among themselves by Tukey test, in the level of $5 \%$ of probability. ** significant $\mathrm{p}<0.01 *$ significant $0.01<\mathrm{p}<0.05$. 
Table 2. Number of grains per row and grains per cob, number of plants per hectare, 100-grain weight, and corn grain yield as a function of $\mathrm{P}_{2} \mathrm{O}_{5}$ dose and source ${ }^{(1)}$. Selvíria - MS, 2008/09 and 2009/10.

\begin{tabular}{|c|c|c|c|c|c|c|c|c|c|c|}
\hline & \multicolumn{2}{|c|}{$\begin{array}{l}\text { Number of grains } \\
\text { per row }\end{array}$} & \multicolumn{2}{|c|}{$\begin{array}{c}\text { Number of grains } \\
\text { per cob }\end{array}$} & \multicolumn{2}{|c|}{$\begin{array}{l}\text { Number of plants } \\
\text { ha }^{-1}\end{array}$} & \multicolumn{2}{|c|}{$\begin{array}{l}\text { 100-grain weight } \\
(\mathrm{g})\end{array}$} & \multicolumn{2}{|c|}{$\begin{array}{l}\text { Grain yield } \\
\mathrm{h}\left(\mathrm{kg} \mathrm{ha}^{-1}\right)\end{array}$} \\
\hline & $2008 / 09$ & $2009 / 10$ & $2008 / 09$ & $2009 / 10$ & $2008 / 09$ & $2009 / 10$ & $2008 / 09$ & $2009 / 10$ & $2008 / 09$ & $2009 / 10$ \\
\hline \multicolumn{11}{|l|}{ P sources } \\
\hline MAP & $31.9 \mathrm{a}$ & $35.2 \mathrm{a}$ & $558.7 \mathrm{a}$ & $573.0 \mathrm{a}$ & $55061 \mathrm{a}$ & $53437 \mathrm{a}$ & $30.9 \mathrm{a}$ & $33.5 \mathrm{a}$ & $8298 \mathrm{a}$ & $8287 \mathrm{a}$ \\
\hline Coated MAP & $33.0 \mathrm{a}$ & $35.6 \mathrm{a}$ & $572.9 \mathrm{a}$ & $564.9 \mathrm{a}$ & $55139 a$ & $52062 \mathrm{a}$ & $31.7 \mathrm{a}$ & $33.7 \mathrm{a}$ & 8440 a & $8423 \mathrm{a}$ \\
\hline D.M.S. (5\%) & 1.6 & 1.5 & 25.7 & 33.1 & 4500 & 1986 & 0.8 & 0.7 & 423 & 344 \\
\hline \multicolumn{11}{|l|}{$\begin{array}{l}\text { Doses of } \mathrm{P}_{2} \mathrm{O}_{5} \\
\left(\mathrm{~kg} \mathrm{ha}^{-1}\right)\end{array}$} \\
\hline 0 & 32.25 & 34.8 & 582.3 & 569.5 & 51384 & $48750^{*}$ & 31.4 & 33.7 & $7465^{* *}$ & $6359^{* *}$ \\
\hline 50 & 32.50 & 36.6 & 549.4 & 591.9 & 56250 & 54000 & 30.4 & 33.3 & 8601 & 8660 \\
\hline 100 & 32.25 & 35.5 & 567.5 & 567.4 & 57494 & 53750 & 32.0 & 33.3 & 8889 & 9218 \\
\hline 150 & 32.88 & 34.9 & 564.3 & 547.0 & 55272 & 54500 & 31.5 & 34.1 & 8522 & 9273 \\
\hline General Mean & 32.5 & 35.4 & 565.8 & 568.9 & 55094 & 52750 & 31.3 & 33.6 & 8369 & 8355 \\
\hline C.V. $(\%)$ & 6.7 & 5.8 & 6.2 & 7.9 & 11.1 & 5.1 & 3.5 & 2.95 & 6.89 & 5.59 \\
\hline
\end{tabular}

Working with residual doses $(0,50,100$, and $150 \mathrm{~kg} \mathrm{ha}^{-1}$ ) and conventional or coated MAP as $\mathrm{P}$ sources under similar edaphoclimatic conditions, Gazola et al. (2013) also verified the influence of P dose on leaf $\mathrm{P}$ concentration in corn with maximum at an approximate dose of $115 \mathrm{~kg} \mathrm{ha}^{-1}$ of P. It is worth mentioning that leaf $\mathrm{P}$ concentration for the different $\mathrm{P}$ doses and forms of MAP were within the reference range (2.0 to $4.0 \mathrm{~g} \mathrm{~kg}^{-1}$ of $\mathrm{P}$ ) described by Cantarella et al. (1997). Thus, the doses of phosphorus applied in both crops were sufficient to maintain the concentration of this nutrient in the leaves without compromising crop development.

Similar results were also reported by Foloni et al. (2008), working with doses of $\mathrm{P}_{2} \mathrm{O}_{5}(0,100,200$,
300 , and $400 \mathrm{~kg} \mathrm{ha}^{-1}$ ), which confirmed increase in concentrations and accumulation of $\mathrm{P}$ in the aerial parts with increasing dose. Testing doses of $\mathrm{P}_{2} \mathrm{O}_{5}$ $\left(0.50,100\right.$, and $\left.150 \mathrm{~kg} \mathrm{ha}^{-1}\right)$ in the conventional triple superphosphate and coated triple superphosphate sources, Valderrama et al. (2011) showed a positive response by leaf $\mathrm{P}$ at concentrations up to $127 \mathrm{~kg}$ ha-1 of $\mathrm{P}_{2} \mathrm{O}_{5}$. Similarly, Harger et al. (2007), studied the effect of $\mathrm{P}_{2} \mathrm{O}_{5}$ doses from 0 up to $180 \mathrm{~kg} \mathrm{ha}^{-1}$ of $\mathrm{P}_{2} \mathrm{O}_{5}$ and triple superphosphate and Arad phosphate as sources. They concluded that the increase of $\mathrm{P}$ dose caused increase in leaf $\mathrm{P}$ concentration in corn plants for the two studied sources; thus, corroborating our own results. 
Figure 2. $\mathrm{P}$ concentration in leaf tissue $\left(\mathrm{g} \mathrm{kg}^{-1}\right)$ in the 2008/09 (A), 2009/10 (B) harvests, plant height (m) in the 2009/10 harvest, (C) number of plants (plants ha ${ }^{-1}$ ) in the 2009/10 harvest, (D) grain yield ( $\mathrm{kg} \mathrm{ha}^{-1}$ ) in the 2008/09 (E) and 2009/10 (F) harvests as a function of $\mathrm{P}_{2} 0_{5}$ dose. Selvíria - MS, 2008/09 and 2009/10.
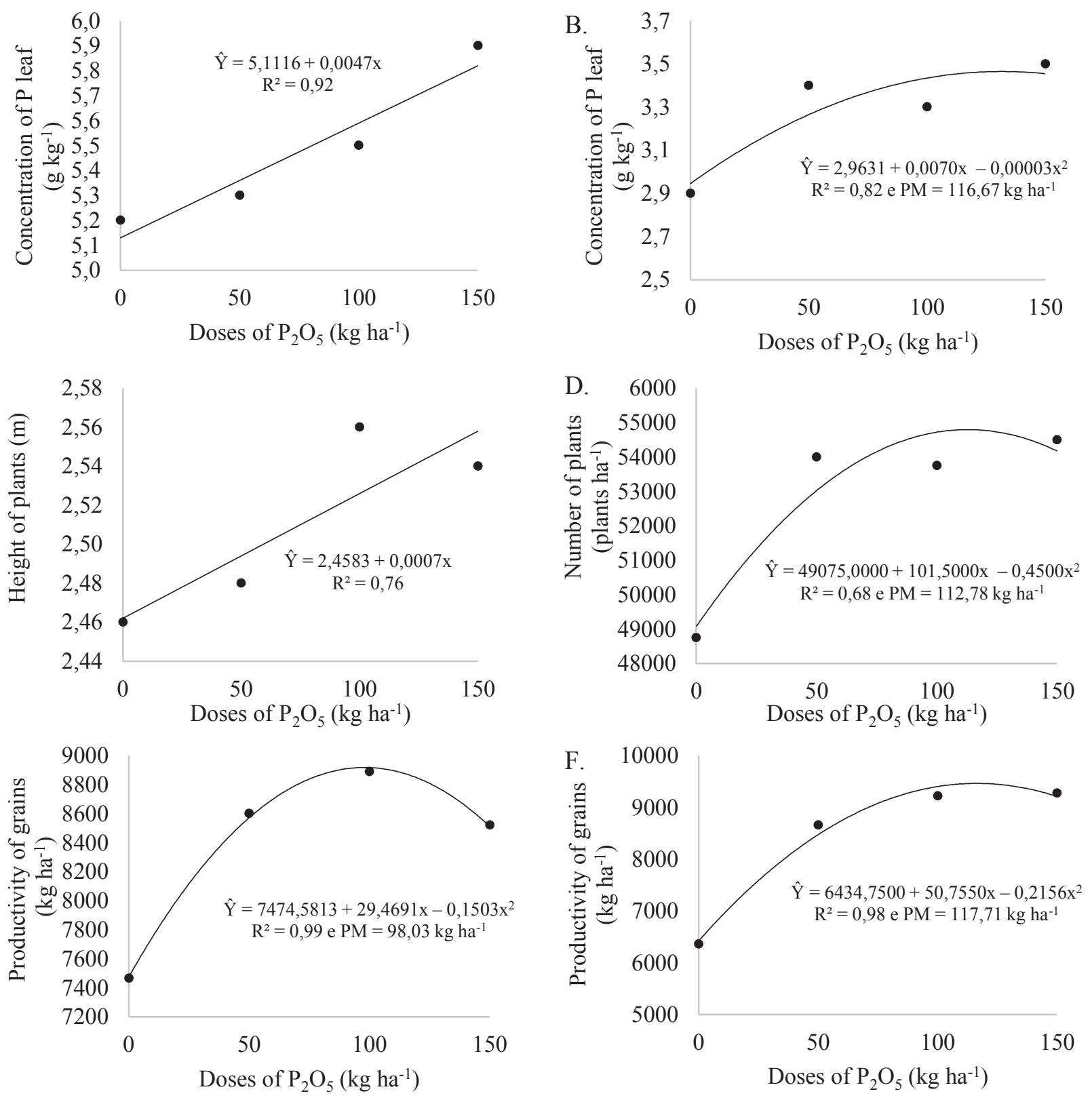

In agreement with our observations, Silva et al. (2012), showed that, regardless of source, the highest $\mathrm{P}$ dose applied promoted the highest aerial $\mathrm{P}$ concentration, which increased by $157.86 \%$, $102.39 \%$, and $35.46 \%$, at 40,60 , and $80 \mathrm{~kg} \mathrm{ha}^{-1} \mathrm{P}_{2} \mathrm{O}_{5}$, respectively. They used untreated MAP, Phosmax, and Phosmax Plus as P sources and five doses: 0,

$40,60,80$, and $120 \mathrm{~kg} \mathrm{ha}^{-1}$ of $\mathrm{P}_{2} \mathrm{O}_{5}$. According to the authors, significant phosphorus accumulation in the aerial part of the plants occurred due to the increase of phosphorus concentration in plant tissue with the increase of phosphorus dose applied to the soil. Brasil et al. (2007), reported similar findings. They studied the influence of P level in 
the nutrient solution on dry matter and nutrient accumulation in eight corn genotypes, in Sete Lagoas, Minas Gerais, Brasil. They confirmed that the higher $\mathrm{P}$ concentration in the nutrient solution resulted in greater accumulation of nutrients in the corn genotypes studied. According to Souza and Lobato (2004), in general for annual grain crops, such as corn and soybean grown in Cerrado soils, the highest productivity increases are observed with doses of up to $300 \mathrm{~kg} \mathrm{ha}^{-1}$ of $\mathrm{P}_{2} \mathrm{O}_{5}$ using soluble sources, values consistent with the results obtained in the present work.

Regarding plant height, similar results were obtained by Gazola et al. (2013), who observed a maximum plant height of $2.10 \mathrm{~m}$ at $150 \mathrm{~kg} \mathrm{ha}^{-1}$ of $\mathrm{P}_{2} \mathrm{O}_{5}$. On the other hand, Oliveira et al. (2009) studied the separate effect of phosphorus and nitrogen dose in a yellow Latosol in a greenhouse and observed a quadratic behavior by phosphorus dose and obtained maximum plant height $(1.08 \mathrm{~m})$ with $137.5 \mathrm{~kg} \mathrm{ha}^{-1}$ of $\mathrm{P}_{2} \mathrm{O}_{5}$. Using the same soil, but under field conditions, Lucena et al. (2000) obtained maximum plant height $(1.46 \mathrm{~m})$ in corn cultivar BR 5033, with application of $100 \mathrm{~kg} \mathrm{ha}^{-1}$ of $\mathrm{N}$; whereas a maximum plant height of $1.51 \mathrm{~m}$ was obtained with application of $177.3 \mathrm{~kg} \mathrm{ha}^{-1}$ of $\mathrm{P}_{2} \mathrm{O}_{5}$. It is interesting to note that the mean plant height obtained in the present study (close to 2.55 $\mathrm{m}$ ), was greater, compared to the aforementioned studies, which is another indication that the crop was not nutrient deficient. It should also be noted that excessive plant height is not a desired feature, as there is a tendency to increased lodging in such cases.

Regarding the number of plants per hectare, phosphorus is a nutrient that directly influences initial crop establishment, mainly during the initial stages of development of the root system. Theoretically, the plant that does not have available phosphorus in adequate concentrations at this stage will not be able to develop properly, compromising plant population and the whole crop, if the corn plant does not grow. Although soil $\mathrm{P}$ content was considered within the average range (16 to $40 \mathrm{mg} \mathrm{dm}^{-3}$ ), fertilization with $\mathrm{P}_{2} \mathrm{O}_{5}$ favored better initial crop establishment, which reflected in the number of plants per hectare during the 2009/10 crop season. Although the dose effect was not significant in the 2008/09 season, plant population increase between the control dose and $150 \mathrm{~kg} \mathrm{ha}^{-1}$ of $\mathrm{P}_{2} \mathrm{O}_{5}$, averaged 3,888 plants per hectare (from 51,384 to 55,272). This observation is consistent with those by Valderrama et al. (2011), who studied $\mathrm{P}_{2} \mathrm{O}_{5}$ dose effect $(0,50,100$, and 150 $\mathrm{kg} \mathrm{ha}^{-1}$ ) on plant population. They did not find any treatment differences on the number of plants per hectare, although the increase in population from the control dose up to $150 \mathrm{~kg} \mathrm{ha}^{-1}$ averaged 3,333 plants per hectare (from 60,778 to 64,111 ).

There was no effect of $\mathrm{P}$ dose or source on yield components, including grain or cob grain number per row nor grain number per cob. This result corroborates a report by Lopes et al. (2007), who proposed that the relationships between cob characteristics are dependent on the genotype. According to Cruz et al. (2003), the hybrid is responsible for $50 \%$ of the final grain yield. Although the number of rows and grains per cob are directly influenced by the genetics of each material, three factors are of extreme importance for each genotype to express its full potential: availability of water, availability of nutrients, and climate. In relation to the availability of nutrients, more specifically phosphorus, the factor under study in the present work, available P content in the soil, which was average according to Raij et al. (1997), was probably enough to supply the crop needs to express its full genetic potential in terms of number of grains per row or per cob.

Regarding grain yield, many researchers have reported positive responses of corn to phosphate fertilization, such as Prado et al. (2001). They observed a linear increase in grain yield up to 135 $\mathrm{kg} \mathrm{ha}^{-1}$ of $\mathrm{P}_{2} \mathrm{O}_{5}$ applied in both, single and double groove sowing. Lucena et al. (2000), also verified an increase in corn grain yield up to $197 \mathrm{~kg} \mathrm{ha}^{-1}$ applied in the sowing groove. Similar results were 
obtained by Gazola et al. (2013). In this case, the response in corn crop productivity occurred up to $118 \mathrm{~kg} \mathrm{ha}^{-1}$ of $\mathrm{P}_{2} \mathrm{O}_{5}$, similar to the present study in the 2009/10 harvest, regardless of $\mathrm{P}$ source used (conventional and coated MAP). It is also close to the economically feasible dose for corn $\left(120 \mathrm{~kg} \mathrm{ha}^{-1}\right.$ of $\mathrm{P}_{2} \mathrm{O}_{5}$ ), according to Silva et al. (2014).

In contrast, Valderrama et al. (2011), studied the effect of $\mathrm{N}, \mathrm{P}$, and $\mathrm{K}$ dose and source on irrigated corn in the Cerrado region. They tested four doses of $\mathrm{P}_{2} \mathrm{O}_{5}: 0,50,100$, and $150 \mathrm{~kg} \mathrm{ha}^{-1}$ and two sources of $\mathrm{P}_{2} \mathrm{O}_{5}$, triple superphosphate and coated triple superphosphate. They did not find any effect of phosphorus dose applied at sowing on corn grain yield under no-tillage, which, according to the authors, probably occurred because of irrigation. They reported an average soil $\mathrm{P}$ content of $31 \mathrm{~g}$ $\mathrm{dm}^{-3}$, according to Raij et al. (1997), and possibly a low $\mathrm{P}$ requirement by the corn hybrid used. This result is not substantiated by our own work, according to which, although the crop was also irrigated and average soil $\mathrm{P}$ content, $22 \mathrm{mg} \mathrm{dm}^{-3}$, was also non-limiting, probably the $\mathrm{P}$ requirement by the hybrid used and its responsiveness to $\mathrm{P}$ were higher, compared to the one used by Valderrama et al. (2011).

Therefore, according to Pavinato and Rosolem (2008), Pereira et al. (2010), and Restelatto et al. (2017), knowledge on management of P fertilization added to the soil and the effect of soil properties on the availability of this nutrient is essential for the long-term planning of fertilization strategies, to maintain or increase satisfactory crop production, especially in soils of tropical regions.

Research related to phosphorus dynamics should increase scientific knowledge, especially to improve dose definition and form of application (SANTOS et al., 2008). Although results in relation to the polymer-coated MAP utilization were moderate, this can be attributed to the soil chemical and mineralogical properties and to the short evaluation period. Thus, new long-term research is necessary, because positive responses to phosphate fertilization are dependent not only on crop species but also on soil mineralogical and soil-climatic characteristics, as observed by Calegari et al. (2013), and Teles et al. (2017).

\section{Conclusions}

Coated MAP and MAP resulted in similar effects on $\mathrm{P}$ concentration in leaf tissue, yield components, and grain yield of the corn crop. Tested P doses favored an increase in leaf $\mathrm{P}$ concentration and corn grain yield, with the former following a linear function whereas the latter followed a quadratic one, up to $98 \mathrm{~kg} \mathrm{ha}^{-1}$, in the 2008/2009 crop cycle.

In the 2009/2010 harvest, plant height increased linearly with increasing phosphorus, with leaf $\mathrm{P}$, number of plants per hectare, and grain yield following a quadratic function up to approximate doses of 117,113 , and $118 \mathrm{~kg} \mathrm{ha}^{-1}$ of $\mathrm{P}_{2} \mathrm{O}_{5}$, respectively, regardless of $\mathrm{P}$ source.

Application of $108 \mathrm{~kg} \mathrm{ha}^{-1}$ of $\mathrm{P}_{2} \mathrm{O}_{5}$, as conventional MAP, is recommended to maximize corn grain yield.

\section{References}

ARAÚJO, F. F. Disponibilização de fósforo, correção do solo, teores foliares e rendimento de milho após a incorporação de fosfatos e lodo de curtume natural e compostado. Acta Scientiarum: Agronomy, Maringá, v. 33, n. 2, p. 355-360, 2011.

BANSIWAL, A. K.; RAYALU, S. S.; LABHASETWAR, N. K.; JUWARKAR, A. A.; DEVOTTA, S. SurfactantModified Zeolite as a Slow Release Fertilizer for Phosphorus. Journal of Agricultural and Food Chemistry, Madison, v. 54, n. 13, p. 4773-4779, 2006.

BRASIL, E. C.; ALVES, V. M. C.; MARRIEL, I. E.; PITTA, G. V. E.; CARVALHO, J. G. Matéria seca e acúmulo de nutrientes em genótipos de milho contrastantes quanto a aquisição de fósforo. Ciência e Agrotecnologia, Lavras, v. 31, n. 3, p. 704-712, 2007. 
CANTARELLA, H.; RAIJVAN, B.; CAMARGO, C. E. O. Cereais. In: RAIJVAN, B.; CANTARELLA, H.; QUAGGIO, J. A.; FURLANI, A. M. C. (Ed.). Recomendações de calagem e adubação para o Estado de São Paulo. Campinas: IAC, 1997. p. 45-71. (Boletim técnico, 100).

CALEGARI, A.; TIECHER, T.; HARGROVE, W. L.; RALISCH, R.; TESSIER, D.; TOURDONNET, S.; GUIMARÃES, M. F.; SANTOS, D. R. Longterm effect of different soil management systems and winter crops on soil acidity and vertical distribution of nutrients in a Brazilian Oxisol. Soil \& Tillage Research, Oxford, v. 133, p. 32-39, 2013.

CHIEN, S. H.; PROCHNOW, L. I.; TU, S.; SNYDER, C. S. Agronomic and environmental aspects of phosphate fertilizers varying in source and solubility: an update review. Nutrient Cycling in Agroecosystems, Dordrecht, v. 89 , n. 2, p. 229-255, 2011.

COLLIER, L. S.; CORREIA, M. A. R.; RAMOS, L. N.; PRADO, R. M.; FLORES, R. A.; NUNES, T. V. Adubação fosfatada no sulco e em faixas sob palhada de leguminosa e produtividade de milho em plantio direto no Tocantins. Revista Ceres, Viçosa, v. 55, n. 2, p. 109116, 2008

CORREAA, R. M.; NASCIMENTO, C. W. A.; FREIRE, F. J.; SOUZA, S. K. S. C.; FERRAZ, G. B. Disponibilidade e níveis críticos de fósforo em milho e solos fertilizados com fontes fosfatadas. Revista Brasileira de Ciencias Agrárias, Recife, v. 3, n. 3, p. 218-224, 2008.

CRUZ, J. C.; VERSIANI, R. P.; FERREIRA, T. R. Cultivo do milho: cultivares. Sete Lagoas: Embrapa, 2003. 3 p. (Sistema de Produção, 1).

EMPRESA BRASILEIRA DE PESQUISA AGROPECUÁRIA - EMBRAPA. Centro Nacional de Pesquisa de Solos. Sistema Brasileiro de Classificação de Solos. 3. ed. Brasília, DF: EMBRAPA, 2013. 353 p.

FIGUEIREDO, C. C.; BARBOSA, D. V.; OLIVEIRA, S. A.; FAGIOLI, M.; SATO, J. H. Adubo fosfatado revestido com polímero e calagem na produção e parâmetros morfológicos de milho. Revista Ciência Agronômica, Fortaleza, v. 43, n. 3, p. 446-452, 2012.

FOLONI, J. S. S.; TIRITAN, C. S.; CALONEGO, J. C.; JUNIOR, J. A. Aplicação de fosfato natural e reciclagem de fósforo por milheto, braquiária, milho e soja. Revista Brasileira de Ciência do Solo, Viçosa, v. 32, n. 3, p. 1147-1155, 2008.

GALINDO, F. S.; TEIXEIRA FILHO, M. C. M.; BUZETTI, S.; SANTINI, J. M. K.; ALVES, C. J.; NOGUEIRA, L. M.; LUDKIEWICZ, M. G. Z.;
ANDREOTTI, M.; BELlOTE, J. L. M. Corn yield and foliar diagnosis affected by nitrogen fertilization and inoculation with Azospirillum brasilense. Revista Brasileira de Ciência do Solo, Viçosa, v. 40, n. 1, p. 1-18, 2016.

GAZOLA, R. N de.; BUZETTI, S.; DINALLI, R. P.; TEIXEIRA FILHO, M. C. M.; CELESTRINO, T. S de. Efeito residual da aplicação de fosfato monoamônio revestido por diferentes polímeros na cultura de milho. Revista Ceres, Viçosa, v. 60, n. 6, p. 876-884, 2013.

GUARESCHI, R. F.; GAZOLLA, P. R.; PERIN, A.; SANTINI, J. M. K. Adubação antecipada na cultura da soja com superfosfato triplo e cloreto de potássio revestidos por polímeros. Ciência e Agrotecnologia, Lavras, v. 35, n. 4, p. 643-648, 2011.

GUPPY, C. N.; MENZIES, N. W.; MOODY, P. W.; BLAMEY, F. P. C. Competitive sorption reactions between phosphorus and organic matter in soil: A review. Australian Journal of Soil Research, Melbourne, v. 43, n. 2, p. 189-202, 2005.

HARGER, N.; BRITO, O. R.; RALISCH, R.; ORTIZ, F. R.; WATANABE, T. S. Avaliação de fontes e doses de fósforo no crescimento inicial do milho. Semina: Ciências Agrárias, Londrina, v. 28, n. 1, p. 39-44, 2007.

HERRERA, W. F. B., RODRIGUES, M.; TELES, A. P. B.; BARTH, G.; PAVINATO, P. S. Crop yields and soil phosphorus lability under soluble and humic-complexed phosphate fertilizers. Agronomy Journal, Madison, v. 108, n. 4, p. 1692-1702, 2016.

JAGADEESWARAN, R.; MURUGAPPAN, V;; GOVINDASWAMY, M. Effect of slow release NPK fertilizer sources on the nutrient use efficiency in turmeric (Curcuma longa L.). World Journal of Agricultural Sciences, New York, v. 1, n. 1, p. 65-69, 2005.

LOPES, S. J.; LÚCIO, A. D.; STORCK, L.; DAMO, H. P.; BRUM, B.; SANTOS V. J. Relações de causa e efeito em espigas de milho relacionadas ao tipo de híbrido. Ciência Rural, Santa Maria, v. 37, n. 6, p. 1536-1542, 2007.

LUCENA, L. F. C.; OLIVEIRA, F. A. Z.; SILVA, I. F.; ANDRADE, A. P. Resposta do milho a diferentes dosagens de nitrogênio e fósforo aplicados ao solo. Revista Brasileira de Engenharia Agrícola e Ambiental, Campina Grande, v. 4, n. 3, p. 334-337, 2000.

MACHADO, V. J.; SOUZA, C. H. E. Disponibilidade de fósforo em solos com diferentes texturas após aplicação de doses crescentes de fosfato monoamônico de liberação lenta. Bioscience Journal, Uberlândia, v. 28, n. 1, p. 1-7, 2012. 
MALAVOLTA, E.; VITTI, G. C.; OLIVEIRA, S.A. Avaliação do estado nutricional das plantas: princípios e aplicações. 2. ed. Piracicaba: POTAFOS, 1997. 319 p.

MALHI, S. S.; HADERLEIN, L. K.; PAULY, D. G.; JOHNSTON, A. M. Improving fertilizer phosphorus use efficiency. Better crops plantfood. Norcross: International Plant Nutrition Institute, v. 85, n. 2, p. 18-23, 2001.

MARTINAZZO, R.; SANTOS, D. R.; GATIBONI, L. C.; BRUNETTO, G.; KAMINSKI, J. Fósforo microbiano do solo sob sistema plantio direto afetado pela adição de fosfato solúvel. Revista Brasileira de Ciência do Solo, Viçosa, v.31, n. 3, p. 563-568, 2007.

MCLAUGHLIN, M. J.; MCBEATH, T. M.; SMERNIK, R.; STACEY, S. P.; AJIBOYE, B.; GUPPY, C. The chemical nature of $\mathrm{P}$ accumulation in agricultural soils implications for fertiliser management and design: an Australian perspective. Plant and Soil, Dordrecht, v. 349, n. 1-2, p. 69-87, 2011.

MELLO, T. F.; BUZETTI, S.; TEIXEIRA FILHO, M. C. M.; GALINDO, F. S.; NOGUEIRA, L. M. Residual effects of nitrogen fertilizer with polymer-coated urea in a corn crop. Revista Caatinga, Mossoró, v. 30, n. 3, p. 586-594, 2017.

OLIVEIRA, F. A de; CAVALCANTE, L. F.; SILVA, da I. F.; PEREIRA, W. E.; OLIVEIRA, de. J. C.; FILHO, J.F.C. Crescimento do milho adubado com nitrogênio e fósforo em um Latossolo Amarelo. Revista Brasileira de Ciências Agrárias, Recife, v. 3, n. 3, p. 238-244, 2009.

PAVINATO, P. S.; ROSOLEM, C. A. Disponibilidade de nutrientes no solo: decomposição e liberação de compostos orgânicos de resíduos vegetais. Revista Brasileira de Ciência do Solo, Viçosa, v. 32, n. 3, p. 911920, 2008.

PEREIRA, M. G.; LOSS, A.; BEUTLER, S. J.; TORRES, J. L. R. Carbono, matéria orgânica leve e fósforo remanescente em diferentes sistemas de manejo de solo. Pesquisa Agropecuária Brasileira, Brasília, v. 45, n. 5, p. 508-514, 2010.

PRADO, R. M.; FERNANDES, F. M.; ROQUE, C. G. Resposta da cultura do milho a modos de aplicação e doses de fósforo, em adubação de manutenção. Revista Brasileira de Ciência do Solo, Viçosa, v. 25, n. 1, p. 8390, 2001.

RAIJ, B. Van; ANDRADE, J. C.; CANTARELlA, H.; QUAGGIO, J. A. Análise química para avaliação da fertilidade de solos tropicais. Campinas: IAC, 2001. 285 p.
RAIJ, B. van; CANTARELLA, H.; QUAGGIO, J. A.; FURLANI, A. M. C. (Ed.). Recomendações de calageme adubação para o Estado de São Paulo. Campinas: IAC, 1997. p. 45-71. (Boletim técnico, 100).

RESTELATTO, R.; MENEZES, L. F. G.; PARIS, W.; SARTOR, L. R.; MARTIN, T. N.; HERRERA, W. F. B.; PAVINATO, P. S. Sorghum and black oat forage production and its nutritive value under phosphate levels. Semina: Ciências Agrárias, Londrina, v. 38, n. 1, p. 429442, 2017.

RODRIGUES, M.; PAVINATO, P. S.; WITHERS, P. J. A.; TELES, A. P. B.; HERRERA, W. F. B. Legacy phosphorus and no tillage agriculture in tropical oxisols of the Brazilian savanna. Science of The Total Environment, Oxford, v. 542, part B, p. 1050-1061, 2016.

SANTOS, D. R.; GATIBONI, L. C.; KAMINSKI, J. Fatores que afetam a disponibilidade do fósforo e o manejo da adubação fosfatada em solos sob sistema plantio direto. Ciência Rural, Santa Maria, v. 38, n. 2, p. 576-586, 2008.

SILVA, A. A.; SILVA, T. S.; VASCONCELOS, A. C. P de; LANA, R. M. Q. Influência da aplicação de diferentes fontes de MAP revestido com polímeros de liberação gradual na cultura do milho. Bioscience Journal, Uberlândia, v. 28, p. 240-250, 2012. Supplement 1.

SILVA, G. F.; OLIVEIRA, F. H. T. PEREIRA, R. G.; SILVA, P. S. L.; TALITA B. A.; DIÓGENES, T. B. A.; SILVA, A. R. C. Doses de nitrogênio e fósforo para produção econômica de milho na Chapada do Apodi, RN. Revista Brasileira de Engenharia Agricola e Ambiental, Campina Grande, v. 18, n. 12, p. 1247-1254, 2014.

SOUZA, D. M. G. de; LOBATO, E. Cerrado: correção do solo e adubação. Brasília: Embrapa Informação Tecnológica, 2004. 416 p.

SOUZA, F. H. S.; TEIXEIRA FILHO, M. C. M.; GALINDO, F. S.; MALMONGE, L. F.; MALMONGE, J. A.; BUZETTI, S. Doses de nitrogênio e modos de aplicação de polímeros orgânicos com ureia dissolvida na cultura do milho. Cultura Agronômica, Ilha Solteira, v. 25, n. 4, p. 361-372, 2016.

TELES, A. P. B.; RODRIGUES, M.; BEJARANO HERRERA, W. F.; SOLTANGHEISI, A.; SARTOR, L. R.; WITHERS, P. J. A.; PAVINATO, P. S. Do cover crops change the lability of phosphorus in a clayey subtropical soil under different phosphate fertilizers? Soil Use and Management, Oxford, v. 33, n. 1, p. 34-44, 2017. 
TIRLONI, C.; VITORINO, A. C. T.; NOVELINO, J. O.; TIRLONI, D.; COIMBRA, D. S. Disponibilidade de fósforo em função das adições de calagem e de um bioativador do solo. Ciência e Agrotecnologia, Lavras, v. 33, n. 4, p.977-984, 2009.

VALDERRAMA, M.; BUZETTI, S.; BENETT, C. G. S.; ANDREOTTI, M.; ARF, O.; SÁ, M. E. Fontes e doses de nitrogênio e fósforo em feijoeiro no sistema plantio direto. Pesquisa Agropecuária Tropical, Goiânia, v. 39, n. 3, p. 191-196, 2009.
VALDERRAMA, M.; BUZETTI, S.; BENETT, C. G. S.; ANDREOTTI, M.; TEIXEIRA FILHO, M. C. M. Fontes e doses de NPK em milho irrigado sob plantio direto. Pesquisa Agropecuária Tropical, Goiânia, v. 41, n. 2, p. 254-263, 2011.

ZHANG, F.; WANG, R.; XIAO, Q.; WANG, Y.; ZHANG, $\mathrm{J}$. Effects of slow/controlled-release fertilizer cemented and coated by nano-materials on biology. Nanoscience, Dordrecht, v. 11, n. 1, p. 18-26, 2006. 